\title{
精神的緊張の測定に関する研究
}

杉本功介・岩 崎 好子*

（昭和 43 年 3 月 8 日 受付）

\section{Study of Measurement of Mental Tension}

\section{Kosuke Sugimoto and Yosiko Iwasaki \\ (Japan Women's College of Physical Education)}

The object of study

In order to measure the mental tension we selected the following 5 phenomena : Electroencephalogram, Microvibration, Galvanic skin reflex, Plethysmogram, Pneumograph, and observed the development of tension from the beginning to the peak of it.

The method of study

The examinees were five women, 21 25 years of age.

We employed following two kinds of suggestion in order to cause mental tension.

Suggestion I. "You shall have an electric shock in 7 minutes from now."

Suggestion 2. "You shall have an electric shock stronger than you had before, in 7 minutes from now." (though it was not really stronger.)

The result of study

(1) The Electroencephalogram, after the beginning of tension, showed a decrease in $\alpha$ wave and an increae in $\beta$ wave.

(2) The Galvanic skin reflex, from the beginning of tension, showed more frequent appearances and larger amplitude.

(3) The Microvibration, as tension rose, showed a decrease in $\alpha$ wave and a conspicuous increase in $\theta$ wave.

(4) The plethysmogram, from the beginning of tension, showed more frequent oscillation of the standard line, but smaller amplitude.

(5) The Pneumograph, from the beginning of tension, showed an increase of frequency in breathing.

(Research Journal of Physical Education, Vol. 13, No. 1, 21 31, 1968)

* 日本女子体育大学 


\section{まえがき}

試合場面等で “あがり”の問題がよく話題に なる。しかし，その実体となるとあいまいな点 が非常に多い，猪飼氏は “あがり”を過度の情 緒的興奮であると考え, 神経生理学の立場から 次のように説明している。「“あがる”といらこ とは，精神的興奮が強いために，神経系全般の 統制が乱れた状態であるといえる。その結果は 精神機能の面にもあらわれてくるが，“あがつ た”ときです筋肉そのものの機能にかわりがあ るわけではないが，意志のと扰りにならないよ らになるのである。」

そこで問題は, 過度の精神的興罍の問題であ る.このような精神的祭張は，自律神経，特に 交感神経に密接な関倸があることが生理学上あ きらかにされている．本研究では自律神経の活 動と関係のある徴細振動 (Microvibration). 脳 波 (Electro-encephalcgraphy)，皮首電気 反射 (Galvanic skin response)，容積脈波抢よび呼 吸の現象を指標として，精神的緊張の生理心理 学的研究を進展させてみたいと思う。

自律神経の興奮性と脳波との間に密接な関倸 があると考えられているが，福島氏らの研究に よれば，副交感神経緊張に傾いている人と，交 感神経緊張に傾いている人とにわけ，その脳波 の平均振幅, 平均周期, 連続度などを比較して みると，副交感型の人では平均振幅，連続度な ど一般に高く，交感型の人では低いといら結論 をだしている。

$\alpha$ 波がもつともよく現われるのは，外来の 刺激がなく，被験者が無念無想の 状態時であ る、刺激を与えて， $\alpha$ 波を消失させる場合に は，その刺激がまず被験者の注意を引くことが 必要である，注意されない刺激は，いかに強い 刺激でも $\alpha$ 波の抑制には有効ではない， $\alpha$ 波 の抑制は外部刺激のみならず，内部的心的状態 の変化によつてる括こりらる，したがつて最す 有効なるのは, 外的刺激の物理的強さではなく て，その刺激がひき拈こす心理的変化，たとえ ば注意，緊張，不安，憑愕といつたことが原因
であると考えられる。

Cohn, R. (1946) は不安，眯念などの場合 の脳波像に 2 つ型があるとみている．第 1 の 型は， $\alpha$ 波が抑制されて小振幅の $\beta$ 波が現わ れる型で，普通の知喾刺激の場合と似ている. 第 2 の型は，大きな振幅の $\beta$ 波が現われ，そ れに $\alpha$ 波が混在しているすのである。この第 2 の型では，多くは感情が高まつて招り，自律 交感神経の 興奮が高くて， G.S.R が現われゃ すい，第 1 の型では深呼吸をさせると，脳波像 が正常にもどることが多いのに，第 2 の型では 深呼吸はあまり有効ではないとしている。

上述したように，脳波と皮層電気 反射の関 係について, Darrow, C.W. \& Cohn, R. らと Forbes らの意見が対立しているが，この点に

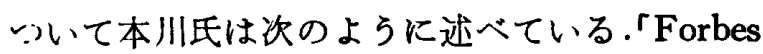
によれば，脳波と皮虐電気反射の間には直接の 関連はないといらが，しかし，特定の場合に は，両者は並行して変化する，また，各種の刺 激によつて，ひき起される G.S.R の大きさと 脳波の変化との 関係は，Forbes の指摘すると 括り，決して一義的なるのではないが，刺激の 種類により，ある法則性は存在する，例えば， 光刺激は脳波の抑制には有効であるが，G.S.R に対してはほとんど無效に近い，凊刺激，電気 刺激は，G.S.R には有効であるが，脳波には あまり有効でない，両現象にともに有効なの は，精神的努力である。」

皮庙電気反射は Veraguth（1904）の実験以 来，心理学的研究がさかんに抢こなわれてき た。この現象と感情，情動などの精神過程との 関係を重視する人もあれば，意志的要素との関 連を主張する人もある。しかし，この現象をあ る特定の精神的過程に特有なものと考之るのは 括そらく正しくなく，瞳孔の反応，血管反射な どと同様に，自律性反射の1つと考えるべきる のであると思う。

感情的表現には自律神経系がはなはだ重要な 役割を果していることを考えると，この現象を 精神医学的, 心理学的研究の一助として用いる ことは大変有意義であると思 5 . 
㣤細振動（Microvibration）と心理的 要因の 関係についてもよく問題になる，日常生活にお いて，緊張した場合手足のふるえを释験するこ とがある。焂細振動は，本人がさほど意識しえ ない緊張状態をる検出することができる，光や 音の刺激を急にあたえると街細振動に変化が打 こる，また暗算を課することを予告しておく と, 安静の状態にもどりにくい。このことは一 種の予期緊張によるものである。自律神経と徵 細振動との関係は, 気温の变化によつて街細振 動が変化することからも推測されるが，自律神 程毒や自律神経遮断剂の作用からも，自律神程 の機能と街勫振動とが密接な関連をもつている ことがわかる。

容積脈波は，血圧，呼吸， G.S.R など他の 自律系反射と同じよ5に，外的括よび内的諸刺 激に対し顕著な反射を示するので，情緒や感情 の鋭敏な指標の1つと考えることがでさる．外 的括よび内的刺激に対する容積脈波の反射に は，2つのものが考えられる。その1つは脈動 波の振幅变動であり，他の 1 つはその基線の動 摇である。

呼吸機能に括いても自律性の反応变化が括こ る。すなわち，感情刺激により呼吸は一時停留 するが，まるなく促迫する．気管支の平滑筋が 弛緩して，気管支が桩張し呼吸しやすくするの である。

以上のように，自律性の反応について，脳 波, 徵細振動, 皮眉電気反射, 容積脈波, 呼吸 の 5 現象から考察してきたのであるが，本研究 ではこの問題について, 生理心理学的な面から 追求したものである.

\section{研究目的}

精神的緊張は自律神経系の活動と密接な関係 があることはいうまでもない．この自律神経活 動より発生する倠細振動をとらえることは，精 神的緊張を測定するのに有効である.ささらに， 自律神経活動の有無, 振幅の大小により, 自律 神経の興檑を知る手がかりとして皮鹿電気反射 がある.この 2 つの現象を指標として，精神的
な緊張の経過を測定し，これと併用して容棈脈 波，呼吸曲線の測定も実施した。しかし，精神 的緊張を測定するには，どうしてる大脳皮質機 能の興奮をとらえる必要が生してくる，そこ で，大脳皮質機能の鋭敏な反応と思われる睬波 によつて，皮質の興賈をとらえることにした。 つぎに，测定する緊張であるが，これは救示に より 7 分間の緊張をとつた。「これから 7 分後 に電気ショックをあたえます。」といら教示を し，さらに緊張を高めるために，3 分前から 1 分毎に時間を知らせた。.この 7 分間に括ける緊 張の生起から, 緊張の高まりの一連の緊張—— これを一種の予期緊張とみなす一一を主に测定 した.

このよらに，緊張の生起から，それがピーク に達するまでの程過を上述した 5 現象（脳波， 徵細振動, 皮庙電気反射, 容積脈波, 呼吸曲 楾）で測定し，各現象の時間的变化および現象 間の関係を調へ，さらにこれらの現象を通じ て，自律神経扣よび大脳皮質の興奮性について 検討を試みた。

\section{研究方法}

(1) 被験者, 21 才 24才の女性 5 名（大学 生)

（2)実験場所，本学心理学実豎室，本実験室 は大電流または雑音の原因になる機器が近接し ているので，これによつて被験者が直接㮇導を 受けないようにシールドルームの中で実験し た。

(3) 実験期間，昭和 42 年 6 月下旬 7 月中 旬.

(4) 実験装置, 脳波計は三栄湘器製の PG602 型ポリグラフを使用した. 脳波のような比 較的急速な変化を示す波形では，時定数を小さ くする必要があるので, 時定数 (time constant) は0.3秒とした。分析装固は三栄測器の EA201 型脳波分析装置を使用した。使用した周波 数帯域は, $\theta$ 帯域 (4〜8c/s)), $\alpha$ 帯域 (8〜13 c/s), $\beta$ 带域 (13〜20c/s) である.

推細振動の Pick up は，日本光龟製のすの 
を使用した。 この Pick up のリード線のチッ プは增幅器としてのポリグラフに接続した。

皮掂電気反射の測定方法には，通電法と電位 法があるが，本実験では電位法によつた，誘導 は右手掌, 右手首より桥導し, 增幅器としての ポリグラフにリード線を接続した。

容積脈波は, 三栄測器盤の反射型光電脈波用 Pick up を使用した。この Pick up のリード 線のチップは, 増幅器としてのポリグラフに接 続した。

呼吸曲線を描くには，胸廍または腹部の運動 を描く方法と，呼吸压を描く方法とがあるが， 本実験では胸䝠の連動を描く方法をとつた。す なわち，硫酸亜鉛の液を充したゴム管の中に亜 鉛電極 2 個をとりつけ，コム管を胸部にまき， 固定した。このリード線のチップは，增幅器と してのポリグラフに接絸した。な招，時定数は 容積脈波とともに 1.5 秒とした。

(5) 誘導方法, 脳波の誘導部位は正中線上の 頭頂部と後頭部で，接地電極を左耳架に装着し た。

皮膚電気反射は右手掌と右手首より誘導し た。な怙右手第 2 指と第 3 指の間，第 3 指と第 4 指の間に電気ショック用のチップのついたり

一ド線を接着固定した。

徵細振動の Pick up は, 被験者の左手の拇 指丘に被験者が気にしない程度にできるだけ軽 く，そしてできるだけ水平に科バンソコウで接 着した。こうして誘導された徴細振動は，分析
器によつて $\theta$ 帯域, $\alpha$ 帯域の瞬時值を記録し た。

容積脈波は，右手第 1 指の指先の血量变化を 測定した。光電脈波用 Pick up は右手第 1 指 の先端に接着した。

呼吸曲線はゴム管を胸部にまき固定し，胸部 運動によつてゴム管が伸縮して変化する両電極 間の電気抵抗を記録した。

(6) 教示の仕方, 上述のように桥導のための 準備がすべて完了したら，実験者は被験者につ ぎのような教示を与えた。

「これから記録をはじめます．記録中はずっ と日を閉じていてくだい，身体や手足はなる ベく動かさないよらに楽な気持でいてくださ い。な招，記録時間は䄪 20 分です。」

(7) 刺激，被験者の緊張していく経過を観察 するために刺激 I，【をあたえた。この刺激は 予期緊張をひき起すためであり，つぎのよらな 教示である．刺激 I 「これから 7 分後に電気シ ヨックをあたえます.」，刺激【「これから７分 後に，さつきより，むつと強い電気ショックを あたえます。」このように刺激をあたえたが， 実際の電気ショックは刺激】と同じ強さのもの である。つぎに，この 7 分間の後半の 3 分間 は，被験者の緊張を高めるために 1 分毎の時間 を報告した。

これらの刺激の呈示時間括よび実験手順は第 1 図のと拝りである.

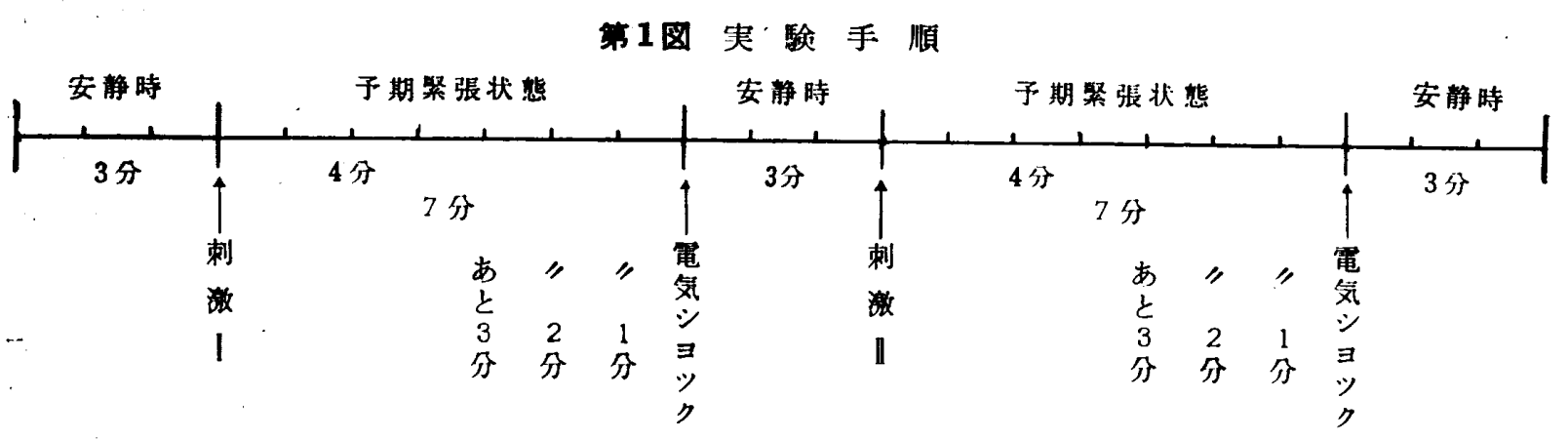

刺 激 I：「これから7分後に電気ショックをあたえます」

刺 激 『I:「これから7分後にさつきよりるつと強い電気ショックをあたえます」

再気ショック：40V(30ッグマ) 


\section{結果なよび考展}

（1）脳波，頭頂部と後頭部からの双極誘導に よつて導出された脳波の分析には，いろいろな 分析法があるが，本実験ではヒストグラム法に よつて，実験開始から1 分毎に10秒間づつの 帯城周波数（ $\alpha$ 波 8 13c/s）( $\beta$ 波 13 20c/s) の出現頻数を測定することにした。

$\alpha$ 波帯域, $\beta$ 波帯域の周波数の出現が時間 経過ととあにどのような変動を示すかについて 調べたのが第 2 図，第 3 図である。

ます安静時（3分間）に打ける $\alpha$ 波の出現 頻数は，刺激 I（これから 7 分後に電気ショッ クをあたえます.)，すなわち予期緊張開始の教 示直後から漸減傾向を示した。 また，電気ショ ック後の安静時（3 分間）に批いては，やや漸 增傾向を示した。しかし，つぎの刺激 II（これ から7分後にさつきより, るつと強い電気ショ ックをあたえます.）によつて， $\alpha$ 波の出現頻 数は漸减傾向を示していつたのである。しか
し, 安静時, 予期緊張時にわたつてみられる漸 增减の差は大きいものからわずかなるのまであ り，個人差のあることは認めなければならな い.

つぎに $\beta$ 波の出現頻数についてみると，安 静時（3 分間）に括ける顕著な 增减はみられな かつたが，刺激 Iより全被験者とも渐增㑯向を しめした，電気ショック後の安静時では渐減傾 向が認められた。しかし，この㑯向の愳められ ないものがめつたため，明確な傾向を認めるこ とはできないが，刺激】によつて， $\boldsymbol{\beta}$ 波の出 現纮数は溸增傾向を示したのである.

脳波の分析にあたつては，各带域の振幅の問 題，各带域の持続時間の問题る考虑して，その 変動を論じなければならない，しかし，本実験 ではその各帯域の出現頻数の面から検討を加え たのである。この面から云えることは，予期緊 張にともなつて， $\alpha$ 波の出現頻数は漸減傾向 を示すが， $\beta$ 波の出現頻数は漸增傾向を示す ということがわかる。

第2图脳波出現頻数の時閒的变動

（ヒストグラム法よにる分析）被験者：E.S

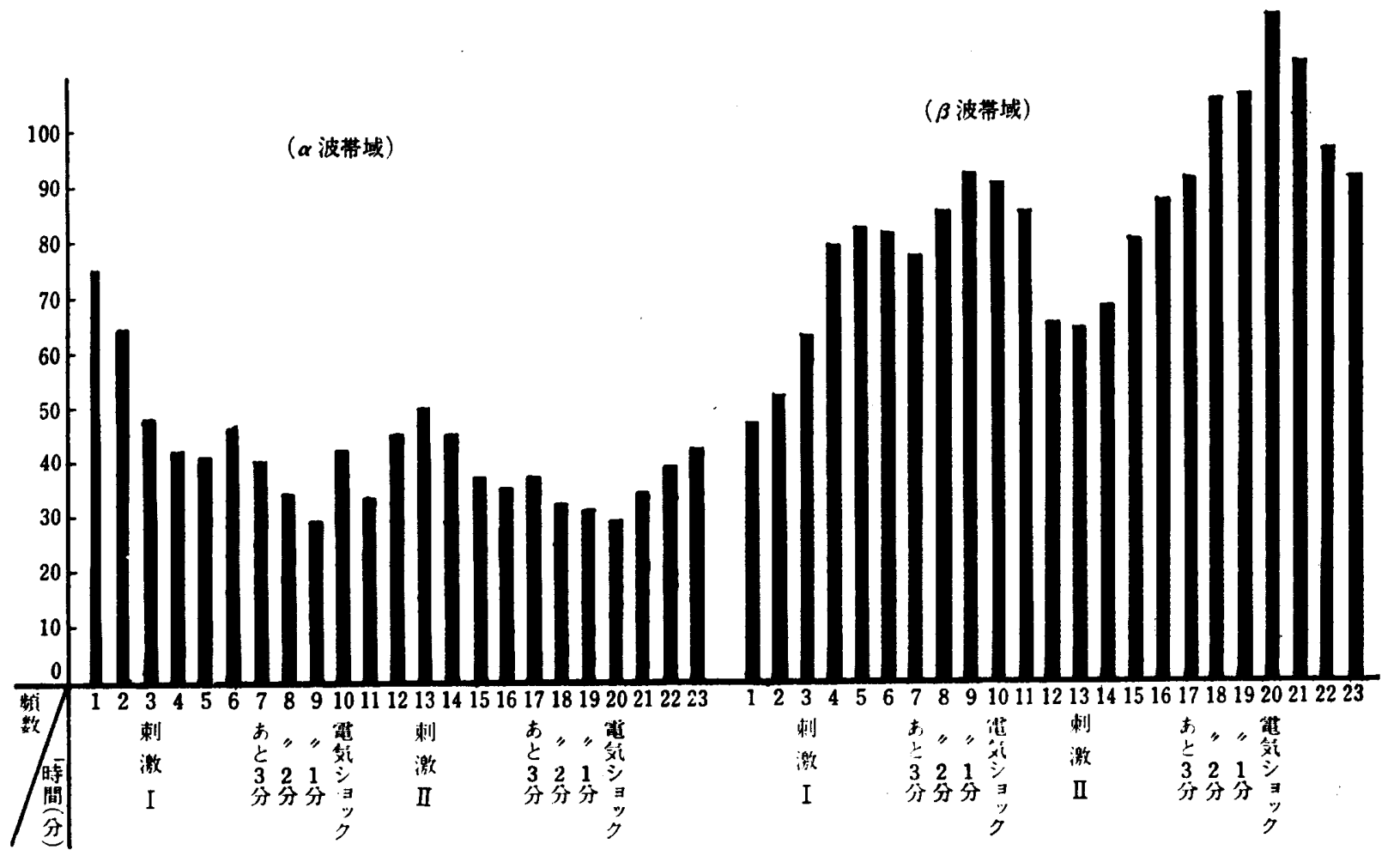


第3图脳波出現頻数の時間的变動 （ヒストグラム法による分析） 被験者：M.K

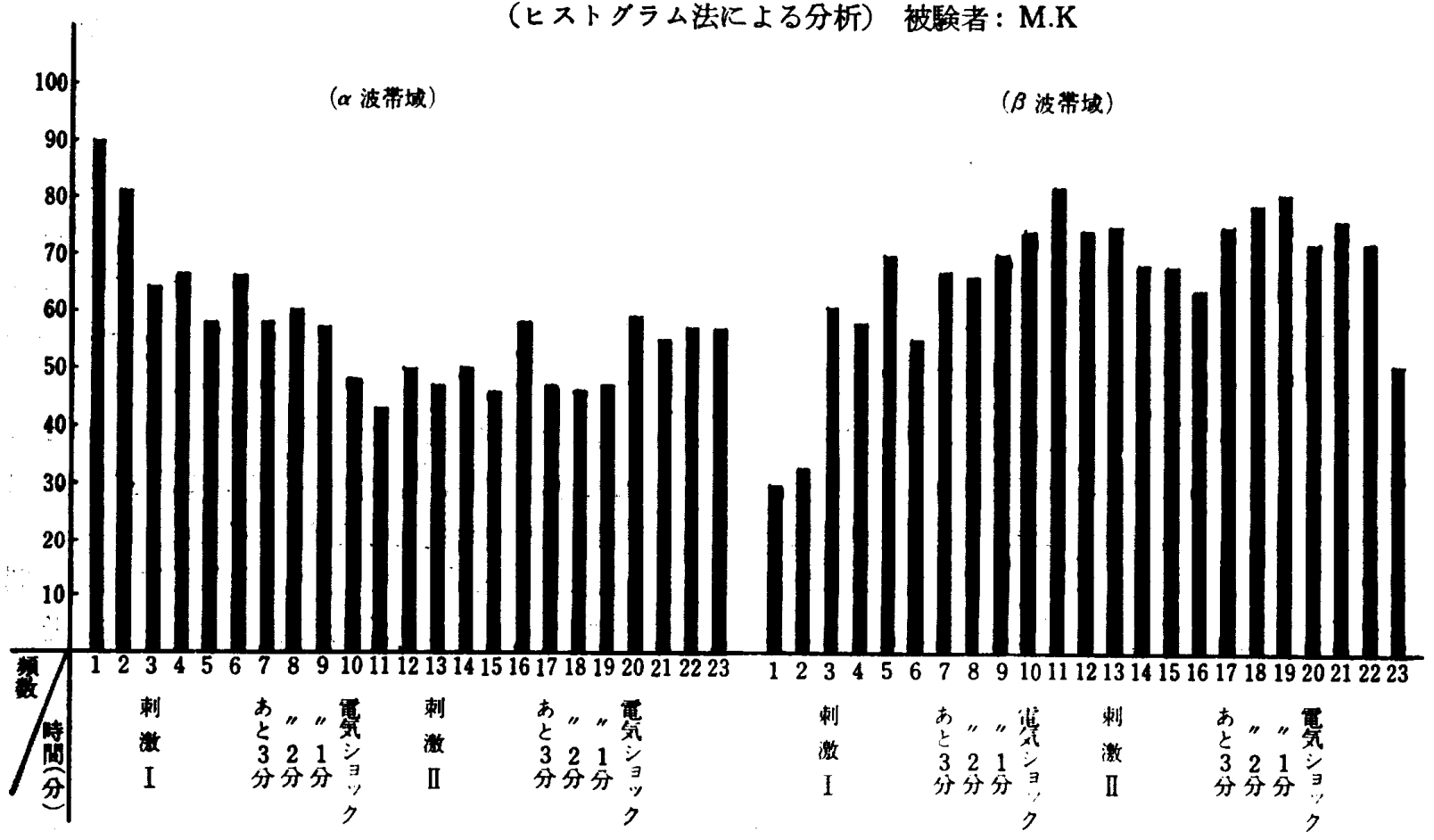

（2）皮店電気反射，ここでは，G.S.R の出現 頻度拈よび振幅の间から考察を加えることにし た。

被験者 R.K の場合をみると，最初の安静時 の自発性の G.S.R はみられないが，刺激 Iか ら，すなわち予期緊張にはいつてから，その出 現が表められる。予期緊張開始からは（1 分〜 4 分）振幅の小さい G.S.R の出現であるが， 5 分〜7分の間では，出現頻度る多く，また振幅
も大きくなつている．刺激【からの予期緊張に なると，出現頻度は刺激 Iの場合より多くなつ ている。このことは刺激【の教示「これから7 分後にさつきよりるつと強い笔気 ショックを あたえます。」によつて，刺激】の場合より， 精神的緊張が高まつたのではないかと思われる (第 4 図参照).

被験者 E.S は，予期緊張にはいつてから， G.S.R の出現頻度も多く, 振幅も大きくなつて

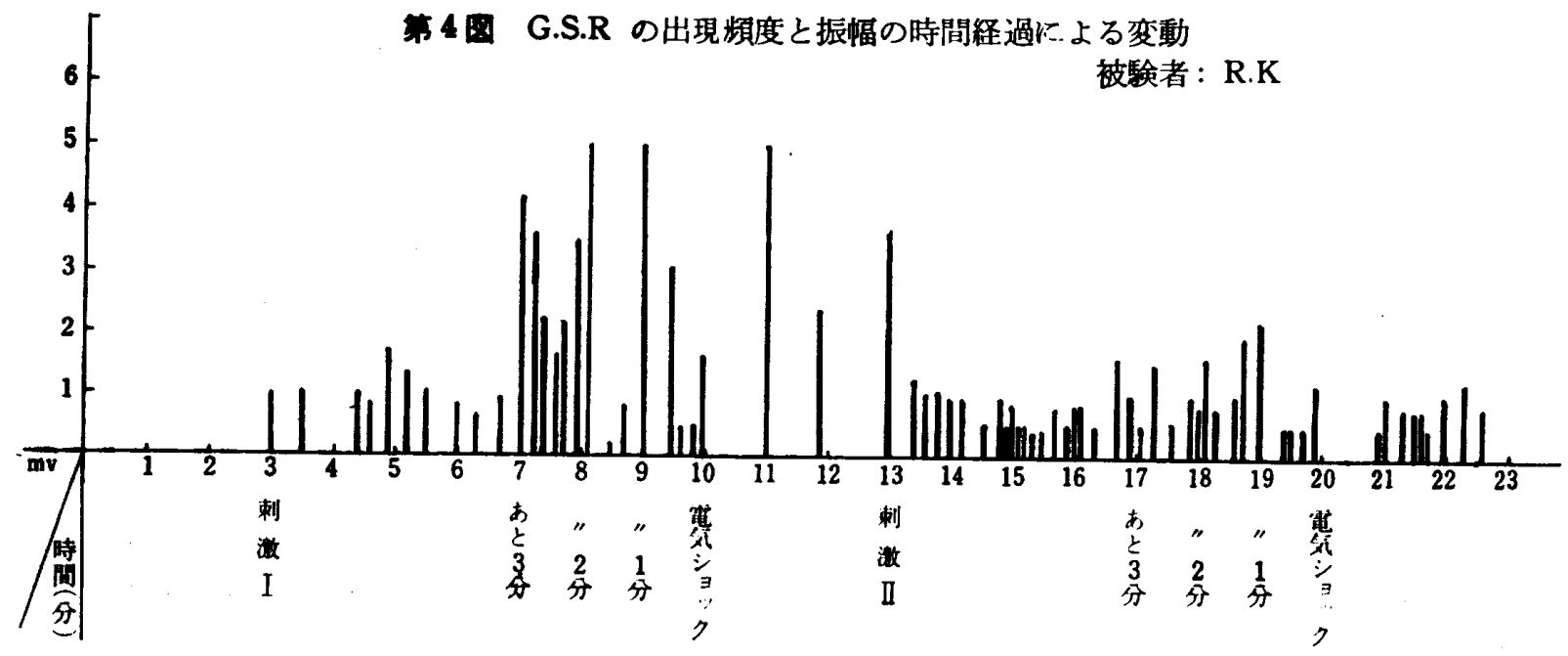


いる，しかし，電気ショック後（3 分間）の G.S.R の出現頻度が多い。さらに刺激】による 予期緊張時になると，振幅る大きく，出現频度 も增す点が目立つている.このように，予期緊 張，電気ショックに対する反応には，個人差の あることはみのがすことができないと思われる (第 5 図参照).

いずれにしても，安静時では，皮原電気反射 の出現はほとんどみられないが，予期緊張には いつてから時間経過にとるなつて，出現頻度る 多くなり，振幅も增大するということができ る.

\section{(8) 徽細 振動}

带域周波数分析装置によつて, $\boldsymbol{\theta}$ 带域, $\alpha$ 带 域の各瞬時值について考察をしてみると，全被 験者とる，安静時に拈いては $\alpha$ 波の出現量が 他の成分より多い。この $\alpha$ 波は，予期㗨張開 始の教示とともに漸減㑯向を示した。しかし， 予期緊張了とともに急激な增加傾向を示した のである。

$\boldsymbol{\theta}$ 波については， $\alpha$ 波の傾向とは逆の傾向 を示した。被験者 R.K は，刺敨】より徐々に 振幅は增大し， $3 \mathrm{mV}$ 強の振幅を示した。そし て予期緊張䅂了とともに減少し，刺激】によつ
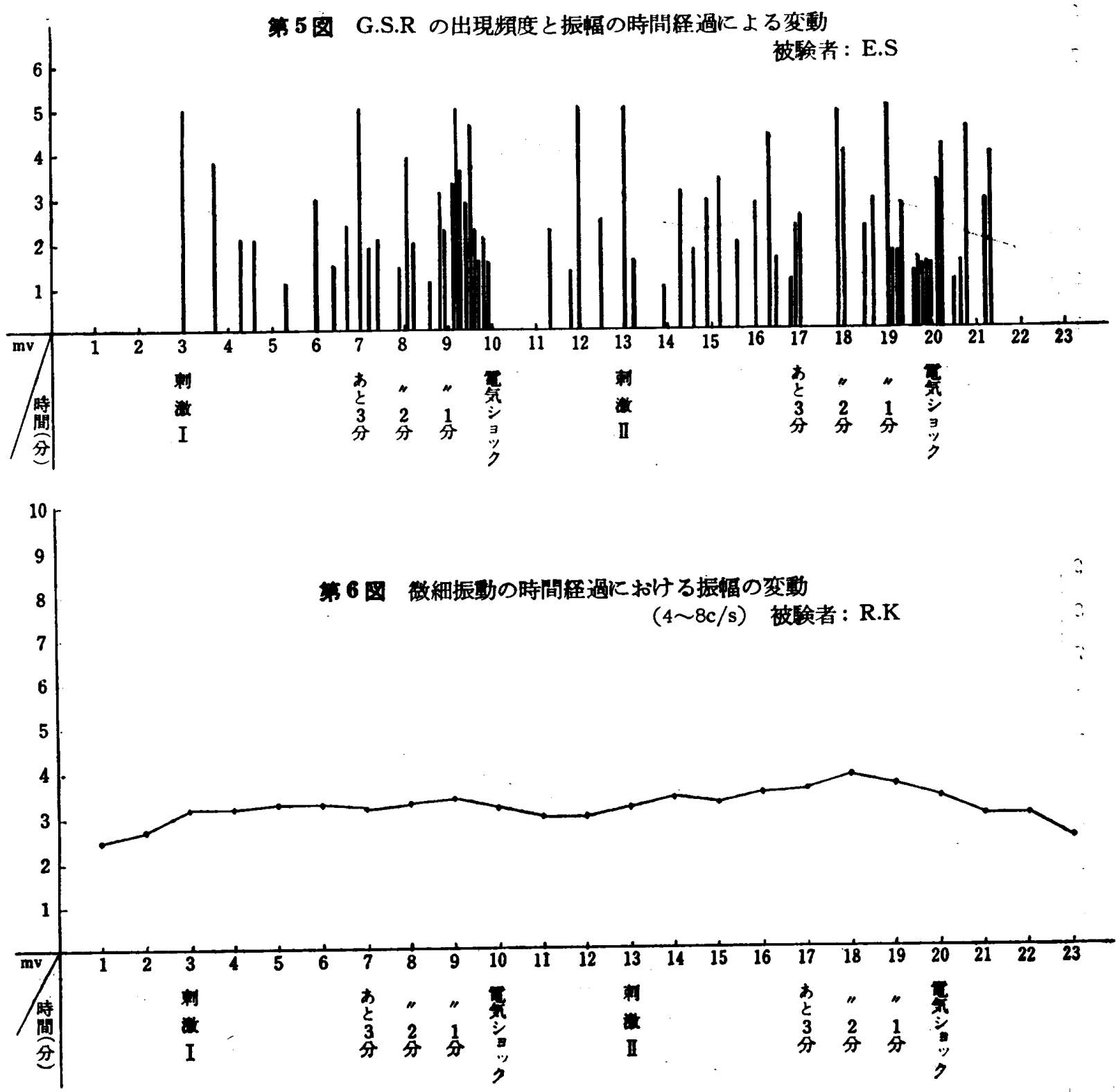
て漸增しているが，予期緊張終了とともに再び 减少するといつた傾向を示したのである（第6 図参照).

被験者 E.S の场合は，安静時に比較して， 予期婜張時の振愊の增大は認めることができる が，その增大のピークは，いずれる予期緊張䅂 了後にあるといらことができる，また，刺湤 I による予期緊張よりも，刺激 Iによよる予期緊張 の方が, $\theta$ 波の振幅に括いて增大が目立つとい うことは，被験者 R.K と異なる点である（第
7 戍参照).

他の被験者す，予期緊張によつて $\theta$ 波の振 愊の增大は認められ，同様に，刺激】による予

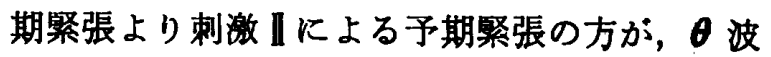
の振幅は增大する傾向が認められた。しかし， 增大のピークが，予期緊張終了の直後にあるの は，被験者 E.S のみであつた。

（4）容積脈波

容積脈波の時間的経過にともなら振幅变動に ついてみたのが，第 8 図，第 9 図である。被験
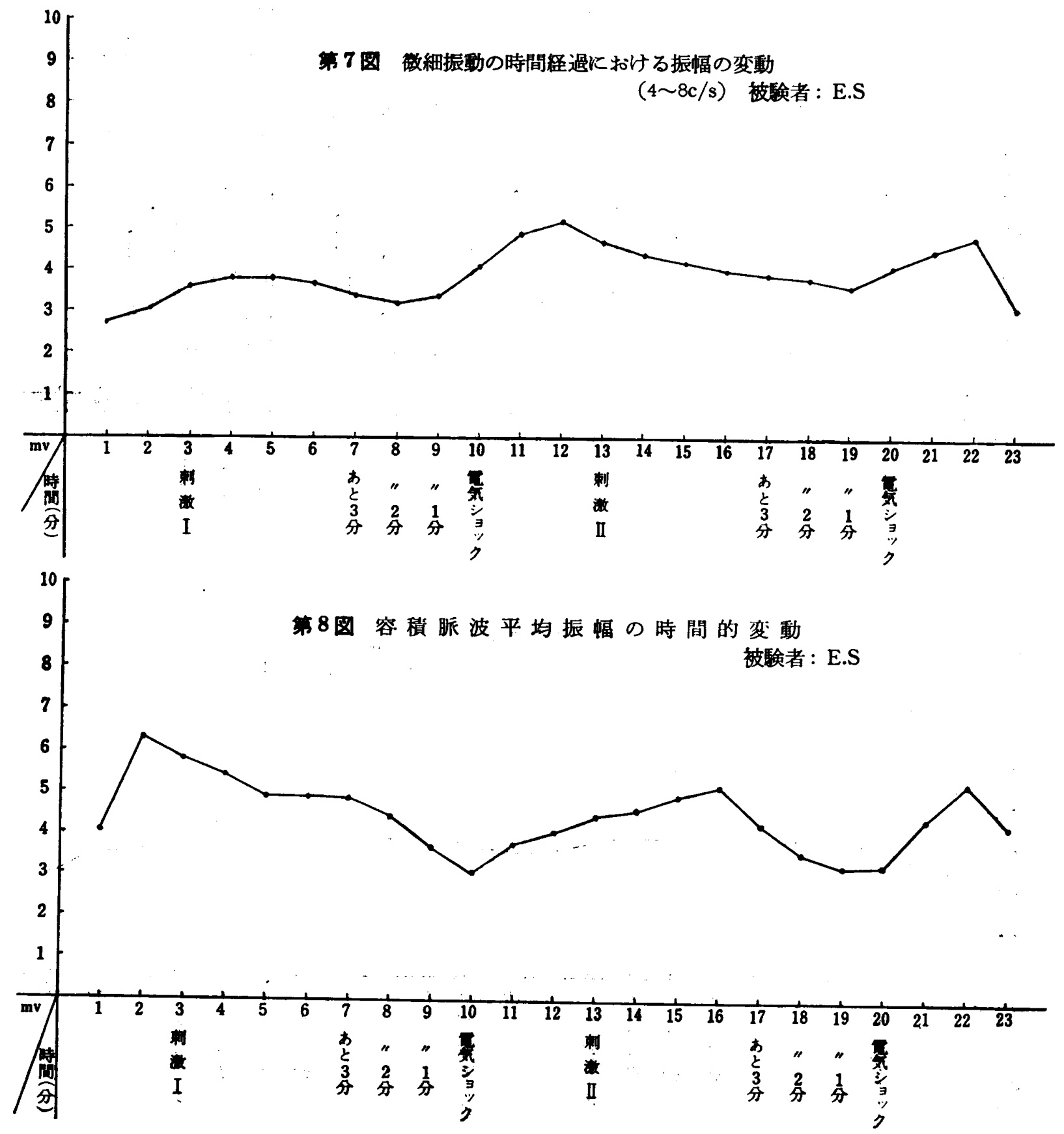


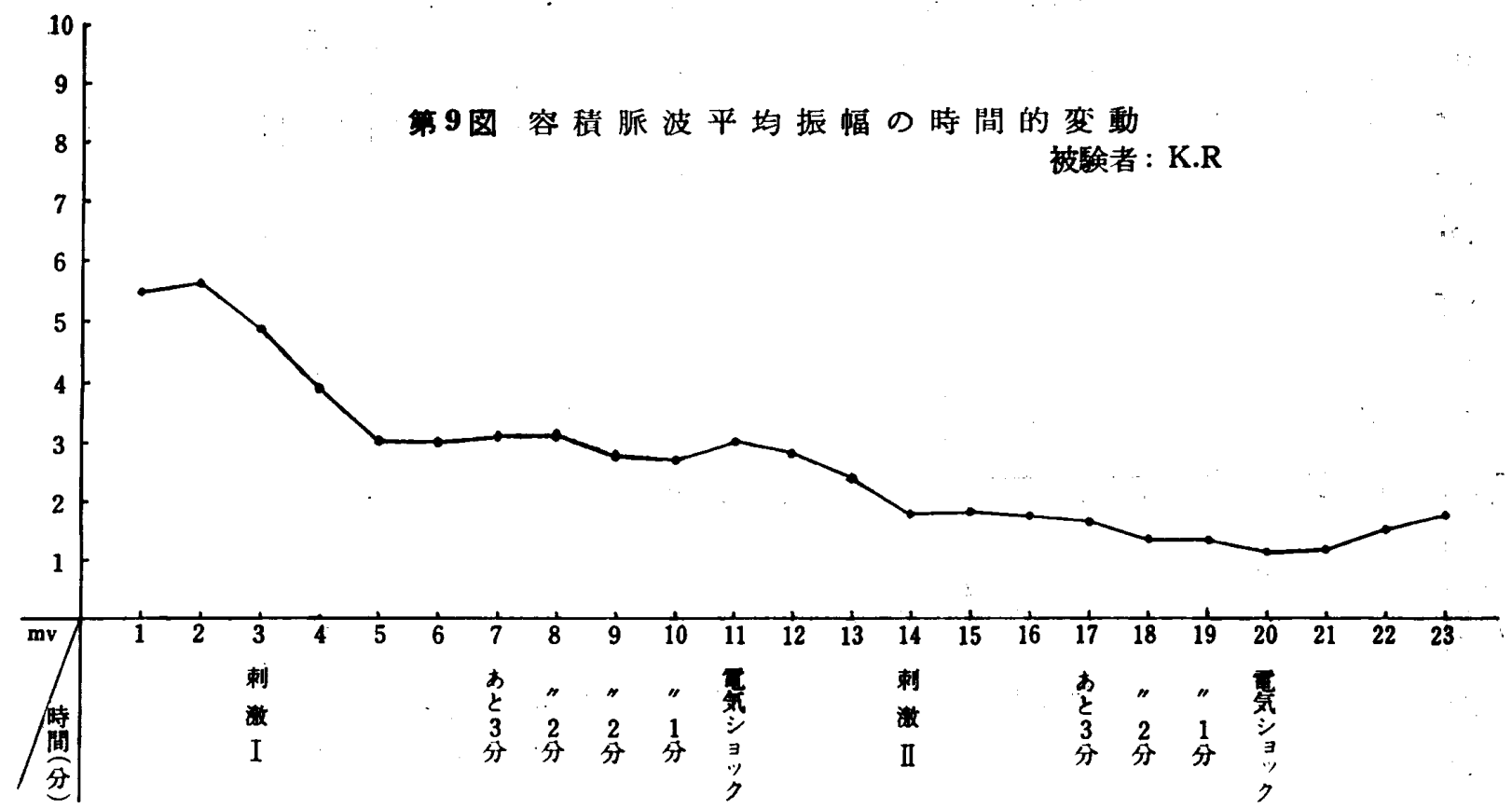

第10図基線の動摇

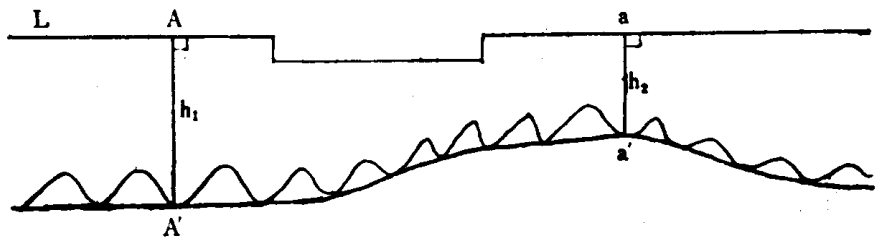

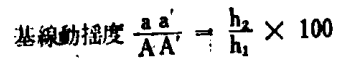

者 E.S の場合は, 刺激 Iより漸减傾向を示し, 予期緊張終了とともに漸增傾向を示している. 刺激【による予期緊張時になつてる減少せず, 電気ショック 4 分前頃から减少し, 予期緊張終 了とともに増大している。被験者 K.R は, 刺 激】によつて減少し, 予期紧張終了直後やや増 大し，刺激【によつてさらに減少している．他 の被験者は大体 E.S と同様で，被験者 K.R だ けが異なつた傾向を示したのである。

つぎに，容積脈波の基線動摇についてである が, 各波の谷と谷とを直線で結び, 安静時にお ける基楾から基準線（L) に垂線を引いた距離 を $\mathrm{A}-\mathrm{A}^{\prime}$ とし，同様に基線動摇時に特けると れを $\mathrm{a}-\mathrm{a}^{\prime}$ であらわし，基線の動播を次の式で あらわし，考察を加えた。

基線動摇度 $=\frac{\mathrm{aa}^{\prime}}{\mathrm{AA}^{\prime}} \times 100$ (第 10 図参照)
安静時における基線の動摇はまれであるが， まつたく出現しないといらことはない，被験者 R.K は，安静時より予期緊張時に 扎いて，基 線動嵒度も，基䠌動摇の出現頻数も多い（第 11 図参照)。

また，被験者 E.S 西同様の傾向を示してい る.しかし，基線の動摇は R.K より大きいと いらことができる（第 12 㘠参照）。

以上のような傾向は，各例にお゙いて顕䔺に亦 されたといらことはできないが，佰向としてと らえることはできた。

(5) 呼吸曲線

呼吸曲線の時間経過にょける平均振幅の変動 及び呼吸回数の变動をみたが，ある䫅向性を認 めることはできなかつた，しかし，呼吸回数は 予期緊張とともに增加する傾向があるように思 わ机る(第 13 図参照). 

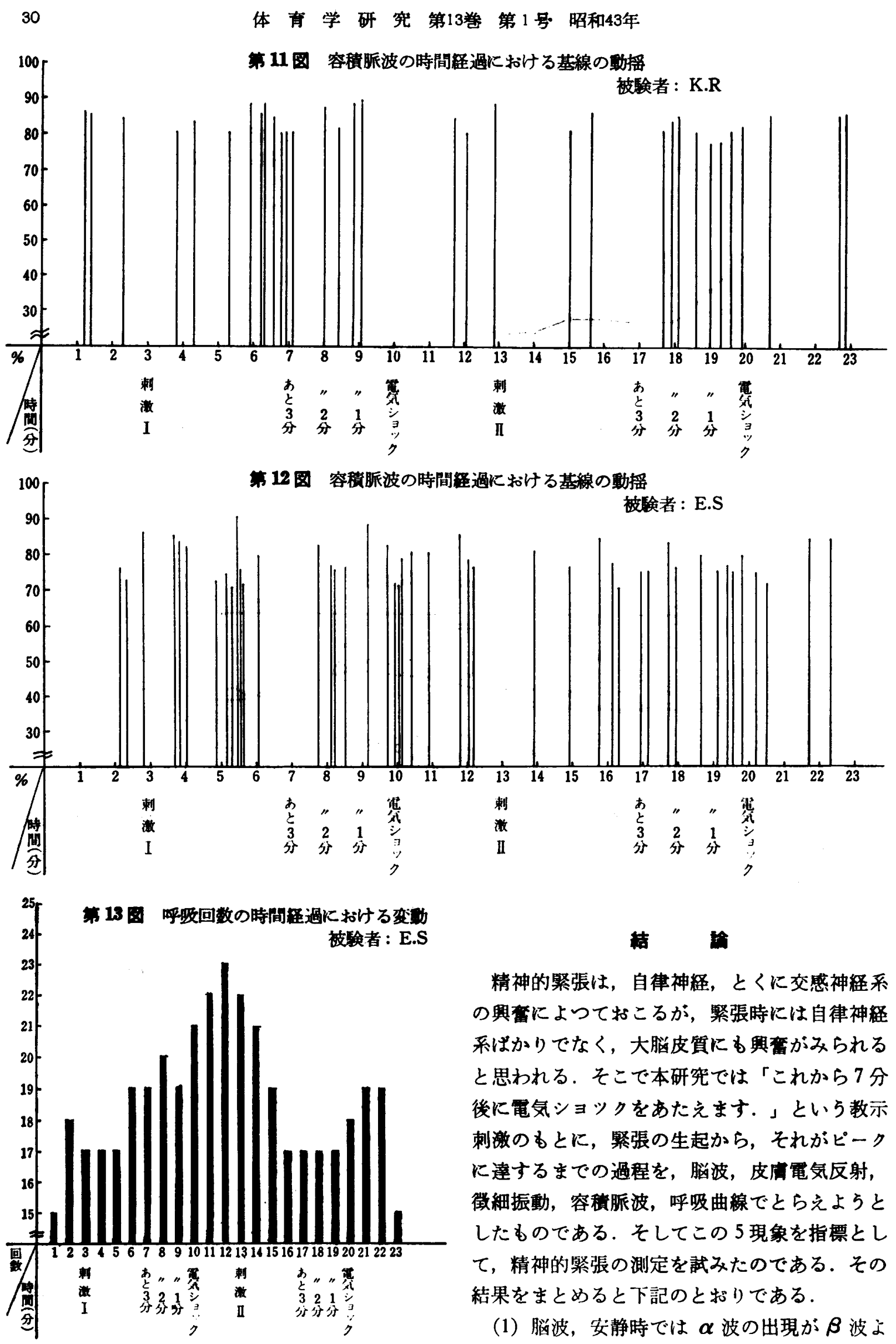

（1）脳波，安静時では $\alpha$ 波の出現が $\beta$ 波よ 
り大でその差は大きい。緊張生起後は， $\boldsymbol{\alpha}$ 波 の減少とともに $\beta$ 波の增加が認められる. ま た $\boldsymbol{\alpha}$ 波は, 安静時に湉いて slow $\boldsymbol{\alpha}$ の周期を もつた波が優勢であるが, 䇣張の高まりにつれ $\tau$, fast $\alpha$ に変化し, 振幅も小さくなる.

（2）皮庙電気反射，安静時では皮膚電気反射 の出現はほとんどみられないが，時間の経過に ともない出現頻数が多くなり，振幅も增大す る.

（3）徵細振動，安静時では $\alpha$ 波の出現が優 性であるが，緊張の高まりにつれて $\alpha$ 波が減 少し， $\boldsymbol{\theta}$ 波の增加が著明になる。

（4）容程脈波, 安静時では基線の動摇扎よび 振幅の変動はみられないが，緊張の生起ととも に，基線の動摇の頻数も多く，動摇の度合も大 になるが，振幅は減少する。

(5) 呼吸曲線, 緊張の生起ととるに, 呼吸回 数が增加する.

以上のような結果から，7分間の緊張にお゙い て，教示刺激をあたえた直後执よび 4 分〜7分 時に緊張の高まりがみられることは明確であ る。しかも, 電気ショツク直前に緊張のピーク
が認められている.したがつて，本研究の目的 である精神的緊張の湘定は，いままでのへてき た各現象の変化であらわすことができると思わ れる。

\section{文堿}

1）啝永和贵：身体表面の徵細振動，矤学出版社， 1966.

2）藏森的一：精神電流現象 (心理学绕座)，中山 書店, 1053.

3）原野広太郎：光電的容積脈波の振幅変動関す 了研究, 日本心理学会第24回大会論文集, 1961.

4) 猪蛤道夫外 2 名：スボーツの生理 学, 同文書 院, 1961.

5）本川弘一：電気生理学，岩波書店，1952.

6) 本川弘一：脳波 (心理学講座), 中山書店, 1953.

7) 本川弘一：大脳生理学, 中山書店, 1964 .

b）新芙良栍外 1 名：G.S.R の研究，心理学研究， 1953.

9）清水健太郎外 3 名：脳波入門，南山堂，1963.

10）若林，森橉：脳波の分析とその応用，医学書 院, 1957. 